\title{
DIVERSIFICATION WITHIN THE MEXICAN VOLE (MICROTUS MEXICANUS) AND THE ROLE OF POST-PLEISTOCENE CLIMATE CHANGE
}

\author{
Dolly L. Crawford ${ }^{1}$, Jerry W. Dragoo ${ }^{2}$, Felisa A. Smith², and Andrea N. Chavez ${ }^{3}$
}

\begin{abstract}
To examine the partitioning of genetic variation within the Mexican vole (Microtus mexicanus), we analyzed variation within the cytochrome $b$ (cyt $b$, ca. $953 \mathrm{bp}$ ) from 44 samples of the Mexican vole from the mountains of the southwestern United States and Mexico. Phylogeographic analyses demonstrated strong support for a western clade and an eastern clade, corresponding to the Sierra Madre Occidental and mountains of the southwestern United States (western clade) and the Sierra Madre Oriental and the Sierra Madre del Sur (eastern clade). Levels of genetic distinctiveness among vole populations in Mexico and the southwestern United States support recognition of the Mogollon vole (Microtus mogollonensis). Estimates of lineage divergence suggested an older divergence for populations in Mexico and a more recent divergence for the presumptive $M$. mogollonensis. Ecological analyses demonstrated a distinct climate niche between vole lineages in the Southwest and Mexico, which indicated the possible role of environmental variation in diversification of the Mexican vole. A similar pattern of climatic separation was also demonstrated between clades of the codistributed taxa Sigmodon hispidus, Neotoma mexicana, and Peromyscus truei, suggesting a broader role for climatic variation in the origin and maintenance of the region's biodiversity.
\end{abstract}

REsumen.-Para examinar la distribución de la variación genética en el metorito mexicano, analizamos la variación en el citocromo $b$ (cyt $b$, c. $953 \mathrm{pb}$ ) en 44 muestras del metorito mexicano de las montañas de México y del suroeste de Estados Unidos. Los análisis filogeográficos demostraron fuerte apoyo para un clado occidental y un clado oriental, correspondientes a la Sierra Madre Occidental y las montañas del suroeste de Estados Unidos (oeste) y la Sierra Madre Oriental y la Sierra Madre del Sur (este). Los niveles de diferencia genética entre las poblaciones de metoritos en México y las del sur de Estados Unidos apoyan el reconocimiento del metorito Mogollon (Microtus mogollonensis) como especie. Las estimaciones de divergencia entre linajes indican una divergencia más remota para las poblaciones en México y una más reciente para el presunto $M$. mogollonensis. Los análisis ecológicos demuestran nichos climáticos distintos entre los linajes de metorito en el suroeste de Estados Unidos y en México, lo cual indica el posible papel de la variación ambiental en la diversificación del metorito mexicano. Un patrón similar de separación climática fue también demostrado entre clados de los taxones codistribuidos: Sigmodon hispidus, Neotoma mexicana y Peromysus truei, sugiriendo que la variación climática tiene un mayor papel en el origen y el mantenimiento de la biodiversidad de la región.

Mixed pine-oak woodlands of the mountainous southwestern United States and Mexico are biologically diverse communities (Eisenberg 1981) and are threatened by human-mediated habitat loss and global climate change (Peterson et al. 2002, Mittermeier et al. 2005). Much of the region's vertebrate diversity is attributable to numerous rodent species that are distributed across the mountainous domain of the southwestern United States and Mexico (Ceballos and Oliva 2006). More than 30 rodent species are found in the region, and at least half are restricted to pine-oak forest at high elevations. Despite the exceptional level of biodiversity, few studies have examined vertebrate diversification in the region (see Sullivan et al. 2000, Leon-Paniagua et al. 2007, and McCormack et al. 2008 for exceptions). Such data are needed to understand processes that promote and maintain vertebrate diversity in the region.

More recent approaches that link statistical phylogeography with ecological modeling may offer new insight into the role of climate on the distribution of genealogical lineages (Knowles et al. 2007, Swenson 2008). The integration of phylogenetic and climate-based modeling of species distributions has been used to examine the association between speciation and shifts in environmental conditions (Peterson et al. 1999, Hugall et al., 2002, Graham et al., 2004). This approach also has utility in examining the relative role of abiotic variation in the genetic structure of montane mammals distributed across Mexico and the southwestern United States.

${ }^{1}$ Cornell Lab of Ornithology, 159 Sapsucker Woods Road, Ithaca, NY 14850. E-mail: dcrawford@ cornell.edu
${ }^{2}$ Department of Biology, University of New Mexico, Albuquerque, NM 87131-0001.

${ }^{3}$ Bureau of Land Management, Albuquerque, NM 87107. 
Montane rodent species that are distributed at elevations between $1700 \mathrm{~m}$ and $3000 \mathrm{~m}$ across the southwestern mountains and Mexico include the Mexican vole, Microtus mexicanus. The species' disjunct distribution in high-elevation grasslands from the Colorado Plateau into southern Mexico (Findley and Jones 1962, Armstrong 1972, Hall 1981, Frey et al. 2002) has led some to suggest that the Mexican vole is composed of at least 2 species: the presumptive Mogollon vole (Microtus mogollonensis) in the United States and the Mexican vole $(M$. mexicanus) in Mexico (Frey and LaRue 1993, Frey et al. 2002). There appears to be support for this suggestion from karyotypic (Modi 1987) and morphological (Frey 1989) analyses. Despite the evidence in support of species recognition, the Mogollon vole is not yet officially recognized (e.g., Fitzgerald et al. 1994, Musser and Carleton 2005). A recent study of allozyme and cytochrome $b$ variation also demonstrated support for specific status of the Mogollon vole, although the cytb data for populations in Mexico was limited to a single population (Frey 2009). Here, we used analyses of the cytochrome $b$ gene of the mitochondrial genome (cytb) to examine partitioning of genetic variation within the Mexican vole. Our samples were drawn from throughout the species' range. Given that species status has not been conferred to the presumptive M. mogollonensis, the taxon was treated as a subspecies of the Mexican vole in all analyses. Subsequently, the possible influence of environmental variation on diversification within and between vole lineages was assessed through analyses of abiotic indices.

\section{Methods}

\section{Climate Modeling}

A dataset of 1486 locality records for $M$. mexicanus from the Global Biodiversity Information Facility (http://data.gbif.org/datasets/ resource), MANIS (www.manisnet.org), and the museum server ARCTOS (http://arctos .database.museum/) was vetted for use in model construction. Vole localities within the United States were assigned a priori as M. mogollonensis and those in Mexico as M. mexicanus. The locality records were proofed for errors or missing latitude and/or longitude data. Duplicate records and records that lacked detailed locality information were excluded. Records with a coordinate precision below $15 \mathrm{~km}$ as calculated in BioGeomancer (Guralnick et al. 2006) were eliminated in order to use only geographically precise records in model construction. The final input data set consisted of 300 records distributed throughout the extant range (Fig. 1).

To examine the generality of a climatedriven pattern in clade divergence, we constructed climate models for the codistributed taxa Peromyscus truei, piñon mouse (Hoffmeister 1951); Sigmodon hispidus, hispid cotton rat (Cameron and Spencer 1981); and Neotoma mexicana, Mexican woodrat (Smith 1997). The species are composed of divergent clades in the southwestern United States and Mexico that have been suggested to be distinct species (Modi and Lee 1984, Janecek 1990, Peppers and Bradley 2000) or highly divergent subspecies (Edwards and Bradley 2002). We also modeled the climatic niche of the closely related congeners, Microtus longicaudus and Microtus californicus (Conroy and Cook 2000a, Conroy and Neuwald 2008). As for the Mexican vole, locality records for each species were obtained from the Global Biodiversity Information Facility and were vetted for geographical precision prior to modeling (S. hispidus, $n=3909$; P. truei, $n=1767 ; N$. mexicana, $n=1013$; M. longicaudus, $n=2738$; M. californicus, $n=99$ ).

The climatic niche of each species (or species complex) was modeled using data representative of conditions during the modern and Last Glacial Maximum (LGM) time periods. The modern climate model was parameterized using 19 bioclimatic indices incorporated as the WorldClim dataset (Hijmans et al. 2005). We also collated data for the LGM for use in hindcasting niches onto past climate landscapes. The climate layers that represented the LGM were based on Community Climate System Model (CCSM; http://pmip2.lsce.ipsl.fr; Collins et al. 2004, Kiehl and Gent 2004) and were also available as WorldClim data. This LGM model was also parameterized using the 19 bioclimatic variables, which represent summaries of means and variation in temperature and precipitation, and which likely characterize dimensions of climate relevant in determining species distributions (Hijmans et al. 2005).

We constructed climate models in Maxent v.3.3.1 (Phillips et al. 2006, Phillips and Dudik 2008), using the default convergence threshold $\left(10^{-5}\right)$ and regularization parameter $(1)$, but 


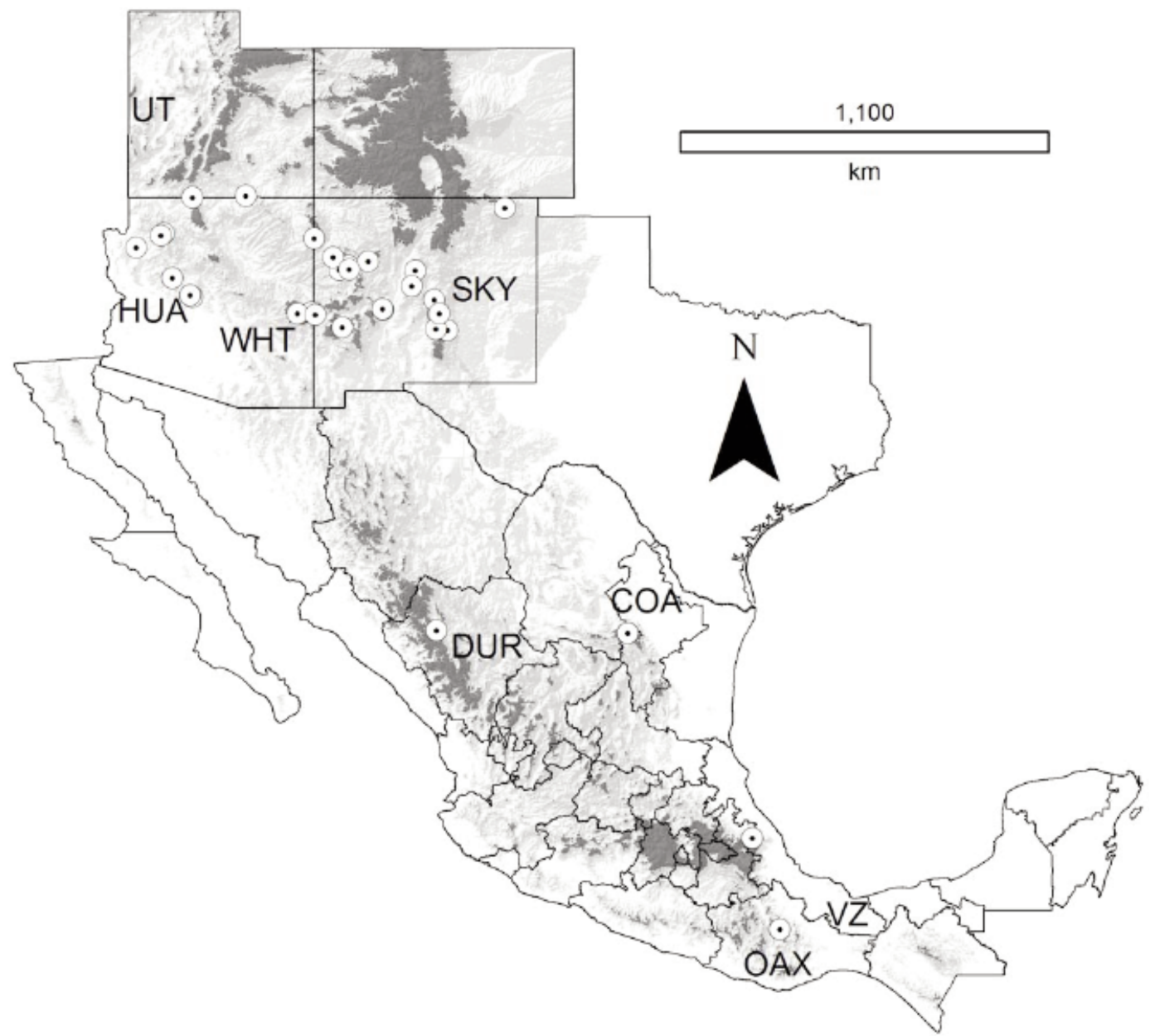

Fig. 1. Geographical distribution of Microtus mexicanus samples analyzed in this study (dotted circles). The distribution of samples examined in genetic analyses included M. m. navaho (Utah, UT), M. m. hualpaiensis (Hualapai Mountains, HUA), M. m. mogollonensis (White Mountains, WHT), M. m. mogollonensis and M. m. guadalupensis (New Mexico, SKY), M. m. madrensis (SMOcc, DUR), M. m. subsimus (SMOr, COA), M. m. mexicanus (SMOr, VZ), and M. m. fulviventer (SMdSR, OAX) (Hall 1981). Mountain range abbreviations for Mexico are as in Table 1. Shading represents elevation projected at $1 \mathrm{~km}$; darker shading depicts elevations greater than approximately $2500 \mathrm{~m}$.

we increased the maximum number of iterations to 2000 . For each run, $75 \%$ of the localities were used to train the model and $25 \%$ of localities were selected for model testing. Once the model construction was complete, the current niche model was projected onto the LGM climate landscape. We assessed model performance using the area under the ROC curve (AUC) statistic (range 0-1.0). The AUC is a robust measure of model accuracy and has been applied successfully to evaluate several modeling approaches (Elith 2002).

To assess the relative influence of environmental conditions on diversification over time, we extracted the values of 19 abiotic parameters for both modern and Last Glacial Maximum (LGM, ca. $15 \mathrm{kyr}$ ) climate scenarios in a GIS. Following the extraction, we conducted multivariate analyses of climatic parameters on vole clades. Clades were assigned based on phylogeographic analyses (M. mexicanus, this study; S. hispidus, Peppers and Bradley 2000; N. mexicana, Edwards and Bradley 2002; P. truei, Janecek 1990; M. longicaudus, Conroy and Cook 2000a; M. californicus, Conroy and Neuwald 2008). All statistical analyses were conducted in PASW Statistics 18, release version 18.0.0 (SPSS, Inc. 2009, Chicago, IL, http://www.spss.com). 


\section{Sampling}

We obtained M. mexicanus tissue samples from the University of New Mexico's Museum of Southwestern Biology (MSB) and skin samples from Michigan State University Museum (MSUM). Samples were selected to provide a representation of the geographic extent of the species (Fig. 1, Appendix). The samples represent 8 of the 12 subspecies of $M$. mexicanus recognized by Hall (1981), including M. $m$. fulviventer $(n=3), M . m$. guadalupensis $(n=$ 6), M. m. hualpaiensis $(n=6), M . m$. mexicanus $(n=3), M . m$. mogollonensis $(n=15)$, M. m. navaho $(n=1)$, and M. m. subsimus $(n$ $=4)$. An additional sample of M. m. guadalupensis $(n=1)$ was downloaded from GenBank (Conroy and Cook 2000b; NK9222). Museum skin samples were obtained from an additional population of M. m. madrensis from MSUM $(n=5)$. Material for the remaining 4 subspecies was not available. For convenience in subsequent analyses, samples were grouped according to the respective mountain regions from which they were collected. The resulting data set included samples from the Hualpai Mountains (HUA, northwestern Arizona), the Colorado Plateau (COP [UT]), the White Mountains (WHT, east central Arizona), the mountains of New Mexico and Utah (SKY), the Sierra Madre Occidental (SMOcc, western Mexico), the Sierra Madre Oriental (SMOR, eastern Mexico), and the Sierra Madre del Sur (SMdSR, southern Mexico; Fig. 1).

To conduct phylogeographic analyses, we sequenced the cytochrome $b$ (cyt $b$ ) gene, which is thought to mutate at a rate suitable for resolving nodes in closely related species that diverged more recently than 2 Ma (Galewski et al. 2006), as suggested for North American Microtus (Conroy et al. 2001). The observed divergence within $M$. mexicanus was examined within the broader context of diversification within Microtus with additional sequences (Appendix). These included a DNA sequence for Myodes gapperi, a recognized outgroup for Microtus (Conroy and Cook 1999, Jaarola et al. 2004). DNA sequences for Microtus californicus, the hypothesized sister taxon to M. mexicanus (Conroy and Cook 2000b), and 15 additional Microtus sequences were also obtained from GenBank. Sequences for M. pennsylvanicus and M. montanus generated during this study were also included in analyses.
Sample Preparation and Sequencing

Genomic DNA from 44 M. mexicanus samples was extracted using a modified salt extraction procedure (Medrano et al. 1990). The cyt $b$ was amplified via the polymerase chain reaction (PCR), primer pair L14724 and H15915 (Irwin et al. 1991), and internal primer pairs MVZ23-MVZ14, MVZ05-MVZ04, and MVZ11MVZ26 (Smith and Patton 1993). Museum skin samples were soaked twice in $10 \%$ SDS solution at $42{ }^{\circ} \mathrm{C}$ for 1 hour to remove potential contaminants prior to extraction. Reaction conditions for PCR were $94{ }^{\circ} \mathrm{C}$ (30 seconds) denaturing, $50{ }^{\circ} \mathrm{C}$ (25 seconds) annealing, and $72{ }^{\circ} \mathrm{C}$ (1 minute) extension. PCR products were purified using the QIAquick PCR Purification Kit (Qiagen, Valencia, CA). PCR templates were prepared for automated sequencing using dyelabeled terminators and cycle-sequencing conditions of $96{ }^{\circ} \mathrm{C}$ (10 seconds) denaturing, $50{ }^{\circ} \mathrm{C}$ (5 seconds) annealing, and $60{ }^{\circ} \mathrm{C}$ (4 minutes) extension. PCR products were sequenced using the same primer sets and purified using a Qiagen DyeEx Spin kit. Skin samples (M. m. madrensis) were amplified and sequenced 3 separate times to assess sequence quality. Sequence samples were read using an ABI 3100 Automated Sequence Analyzer and manually aligned using Sequencher v.4.7 (Bromberg et al. 1995).

\section{Phylogenetic Analyses}

Phylogenetic analyses were conducted to examine the partitioning of genetic variation in M. mexicanus using a Bayesian approach in MrBayes v.3.1.2 (Huelsenbeck and Ronquist 2001). The model of evolution that best fit the data was selected using Modeltest v.3.7 (Posada and Crandall 1998). The Bayesian analysis was conducted using the parameters of 4 chains run simultaneously; each chain ran for 6,000,000 generations and every 1000th tree was sampled. The runs converged onto the stationary distribution of likelihood scores at 38,000 generations. The first 950 trees were discarded so that only parameters estimated after stationarity were used. We also conducted a likelihood analysis using the Genetic Algorithm for Rapid Likelihood Inference (GARLI v.0.96; Zwickl 2006) in order to examine consilience across methods. The GARLI run was performed using 100 replications and the selected model parameters.

Mitochondrial diversity for Mexican vole populations was estimated through genetic parameters theta pi $(\pi)$, theta $(\Theta)$, and the number 
of segregating sites $(S)$ in DnaSP v.4.90 (Rozas et al. 2003). Genetic distances between clades and between subpopulations within clades were estimated as the uncorrected percent divergence (uncorrected p-distance) to allow comparison with other studies of Microtus (Jaarola et al. 2004, Conroy and Neuwald 2008) and were estimated in PAUP v.4.0b10 (Swofford 2002) and MEGA v.4.0 (Tamura et al. 2007). The net divergence between Mexican vole clades was estimated by subtracting the mean within-clade distance from the average between-clade divergence (Avise and Walker 1998, Conroy and Neuwald 2008). Preliminary analyses of the mitochondrial data suggested a bias in the transition-to-transversion substitution rate $(\mathrm{R}=$ 2.5). As a result, pairwise genetic distances were also estimated in MEGA v.4.1 (Tamura et al. 2007) under the Kimura 2-parameter model, which corrects for this bias (Kimura 1980).

\section{Tests of Neutrality}

We assessed neutrality using Fu's Fs (Fu 1997) and Tajima's D (Tajima 1989) test statistics. Each test is sensitive to different violations of neutrality and, as such, can help determine the potential processes influencing genetic structure for species populations. Fu's Fs test of the mismatch distribution is expected to yield significantly negative values in expanding populations, because the number of segregating sites $(S)$ is expected to change more rapidly with changes in population size compared to pairwise nucleotide diversity (ח). Tajima's $D$ is a more conservative test of bottlenecks than Fu's Fs (Crawford 2007). Tajima's D test compares the expected values of segregating sites, $S$, and the standardized number of mutations (as represented by the number of pairwise differences), $\pi$. At equilibrium, $S=\pi$. Changes in population size violate equilibrium. A positive value for Tajima's $D$ indicates evidence of a genetic bottleneck, and a negative value supports population expansion.

A mismatch analysis on the haplotype distributions for Mexican vole populations in the United States and Mexico was performed using 10,000 permutations. In a population that has undergone a recent expansion or genetic bottleneck, the mismatch distribution is expected to be unimodal and to approximate a Poisson curve, as haplotypes spread relatively rapidly across the landscape. A population in mutation-drift equilibrium is predicted to exhibit a multimodal distribution because multiple haplotypes are maintained in stable populations (Harpending 1994). We conducted tests in DnaSP v.4.90 (Rozas et al. 2003) using the default of free recombination and 5000 replications.

\section{Divergence Estimation}

A test for rate homogeneity was conducted among $M$. mexicanus lineages using the likelihood ratio test with $s-2$ degrees of freedom (Felsenstein 1981) to evaluate the application of a molecular clock to the mitochondrial DNA data. Phylogenetic analyses were conducted under the best-fit model HTR + I + G with and without enforcing a strict molecular clock, and the likelihood scores were compared. Results demonstrated significantly different rates of substitution among branches $\left(-\operatorname{lnL} \mathrm{w}_{\mathrm{w} / \mathrm{clock}}=4336.37\right.$, $\left.\ln \mathrm{L}_{\mathrm{w} / \mathrm{o} \text { clock }}=4295.26, \mathrm{df}=42, \mathrm{P}<0.05\right)$, and we deemed the use of a strict molecular clock inappropriate. In the absence of rate homogeneity, we estimated divergence for Mexican vole clades using a relaxed molecular clock assumption in BEAST v.1.4.6 (Drummond et al. 2006). The purpose of relaxed molecular clocks is to obtain divergence estimates while allowing differential evolutionary rates within lineages. Fossil data were used to set calibration priors on nodes in the phylogeny. The use of fossils to set external calibration points is useful because rates of evolution are allowed to vary along the entire branch (rather than concentrating the rate on the node), which tends to yield more robust estimates (Ho 2007). Notably, because the appearance of a fossil in the geologic record likely postdates the origin of its representative lineage, fossil calibration priors represent a minimum age for diversification. When fossils are used as external calibration points, model priors are constrained to be lognormal. A lognormal distribution is more appropriate for modeling the uncertainty surrounding a fossil-based node age compared to a normal distribution, which may set priors that postdate the first appearance of a group in the fossil record (Hedges and Kumar 2004, Drummond et al. 2006, Ho 2007).

To parameterize the model, external calibration priors were set using paleontological data. External calibrations to represent the divergence between Microtus and Myodes were set using a lognormally distributed prior of $3.5 \mathrm{Ma}$ based on fossil evidence (Zakrzewski 1985, Catzeflis et al. 1987, Chaline and Graf 1988). A second calibration prior of $0.5 \mathrm{Ma}$ was set to 
represent the radiation of Microtus in North America (Hoffmann and Koeppl 1985, Repenning 1990).

While fossil data are useful in setting a minimum age for lineage diversification, they can provide misleading results if the timing of the divergence in question is significantly more recent compared to the fossil evidence. In these cases, careful application of an internal calibration prior derived from molecular data can mitigate this temporal disconnect (Ho et al. 2007). A second set of divergence estimates was performed by again setting a $3.5 \mathrm{Ma}$ prior for the divergence of Myodes-Microtus (Chaline and Graf 1988) and an internal calibration prior derived from molecular analyses. The molecularbased prior seemed appropriate, given that, with fossil data, a gap of approximately 3.0 Ma separates the origin of Microtus (approximately 3.5 Ma, range 2.6-4.4 Ma; Chaline and Graf 1988) and the radiation of Microtus in North America (about 0.5 Ma; Hoffmann and Koeppl 1985). To evaluate the possible influence of this $3.0 \mathrm{Ma}$ gap, an internal calibration prior of $1.3 \mathrm{Ma}$ based on molecular analyses (Conroy and Cook 2000b) was used in place of the fossil estimate for the diversification of North American Microtus. A mid-Pleistocene divergence has been suggested for Microtus lineages in Mexico including M. oaxacensis and M. umbrosus (Conroy et al. 2001). A second internal calibration prior of 1.0 Ma was set to represent the divergence of Mesoamerican Microtus (Conroy et al. 2001). Models constructed with fossil-based calibration priors were compared to models that incorporated fossil and molecular priors. Model performance was based on marginal likelihoods and the effective sample size (Drummond and Rambaut 2007). The latter parameters evaluate whether the search algorithm has run long enough to obtain valid estimates of model parameters, and an effective sample size (ESS) value of $\geq 100$ is considered appropriate for robust parameter estimation (Drummond et al. 2006). A Bayesian search of 10,000,000 generations was used for each model run to maximize the effective sample size and minimize the error of divergence estimates (Drummond et al. 2006).

\section{REsults}

\section{Climate Modeling}

Species distribution models and statistical analyses of environmental data demonstrated that vole lineages in the southwestern United States occupy a different climate niche compared to lineages in Mexico. The species distribution models parameterized with modern climate data predicted suitable habitat for the Mogollon vole across the southwestern United States and northern Sierra Madre Occidental and no suitable habitat for the Mexican vole north of approximately $30^{\circ}$ latitude (Fig. 2a, b). This differed from the LGM model, which predicted more extensive suitable habitat for the Mexican vole (Fig. 3a), though much of the suitable habitat for the presumptive Mogollon vole was predicted south of the current distribution and included the Sierra Madre Occidental (Fig. 3b). The AUC for the LGM model was high $\left(\mathrm{AUC}_{\text {train }}=0.988, \mathrm{AUC}_{\text {test }}=0.965\right)$, which suggests that the Maxent distribution is a close approximation of the species distribution for that time period.

Likewise, statistical analyses demonstrated that vole lineages in the southwestern United States occupy a climate distinct from lineages in Mexico for both modern $\left(F_{18,403}=948.64\right.$, $P=0.000)$ and LGM conditions $\left(F_{18,403}=\right.$ 943.33, $P=0.000)$. Samples from Durango, Mexico, were distributed in the same climate space as the rest of Mexico. A plot depicted lower mean annual precipitation and lower overall temperatures for vole locations in the United States, while the opposite was true for locations in Mexico (Fig. 4a, b). This was consistent over both time periods (Fig. 4a, b). Our analyses of 3 codistributed taxa, $M$. longicaudus, and M. californicus also demonstrated significant differences in the climate space occupied by clades within each species. A MANOVA of WorldClim parameters on vole clade was significant for the hispid cotton rat $\left(F_{18,3890}\right.$ $=1703.44, P=0.000)$, the Mexican woodrat $\left(F_{18,994}=378.18, P=0.000\right)$, the piñon mouse $\left(F_{18,1748}=1359.26, P=0.000\right)$, the longtailed vole $\left(F_{162,41656}=344.07, P=0.000\right)$, and the California vole $\left(F_{18,80}=13.27, P=\right.$ $0.000)$. The climate space occupied by sister clades included significant differences in mean annual temperature and/or mean annual precipitation, which were consistent over both time periods (Fig. 5, only modern climate data shown).

\section{Phylogenetic Analyses}

Phylogenetic analyses were conducted on $953 \mathrm{bp}$ from the downstream portion of the 
A

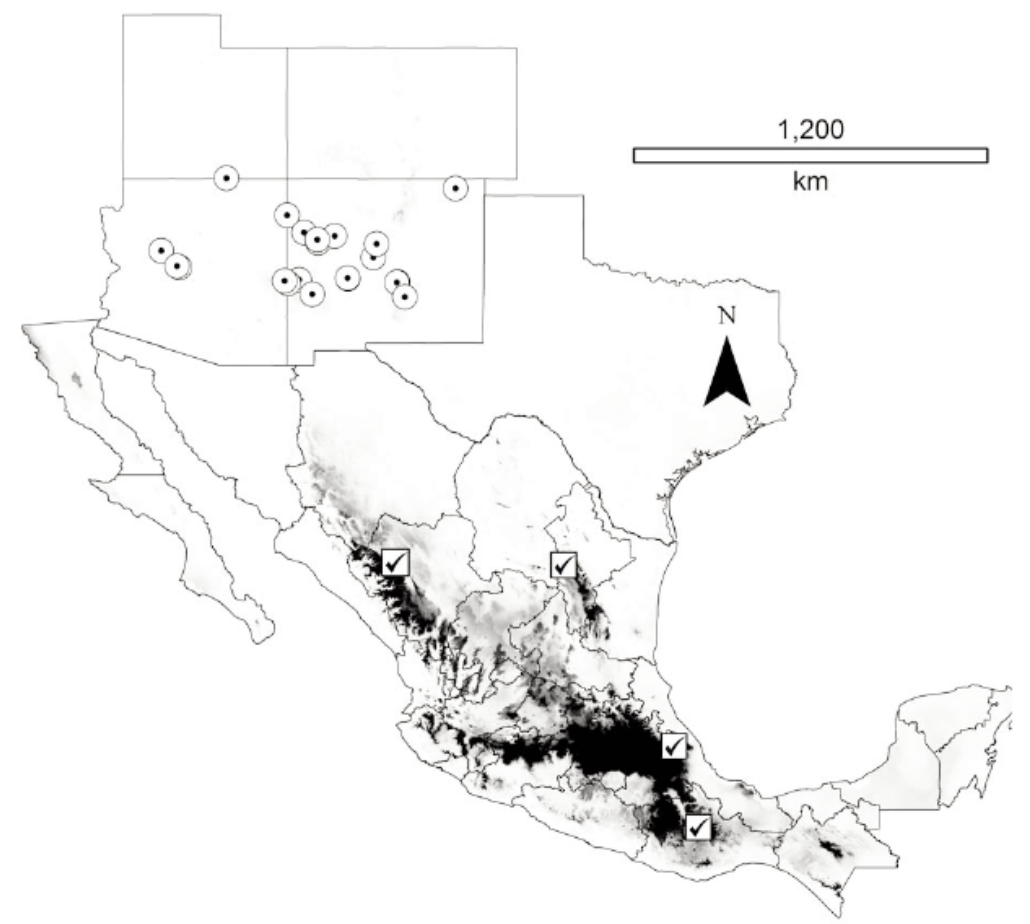

$\mathrm{B}$

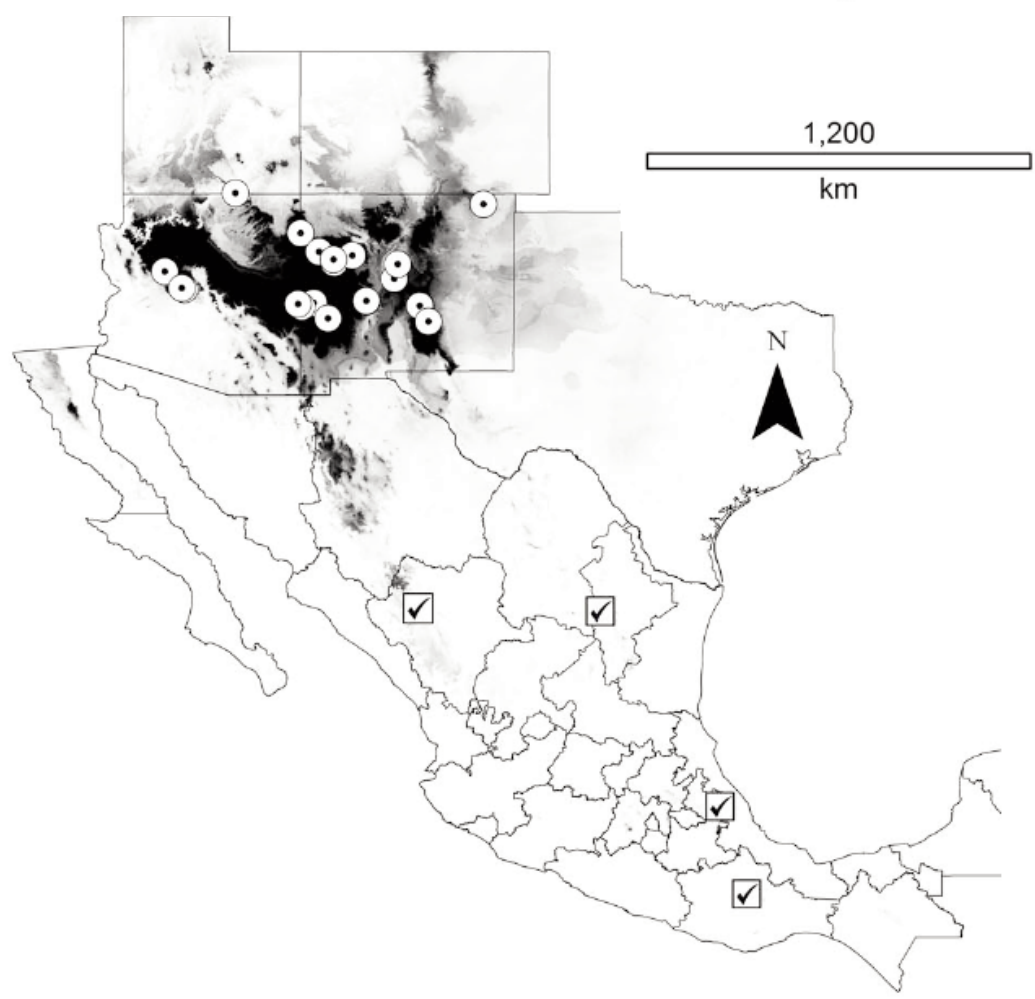

Fig. 2. Ecological niche models based on modern climate conditions: A, Mexican vole (Microtus mexicanus; checked boxes in Mexico [south of approximately $30^{\circ}$ latitude]); B, presumptive Mogollon vole (Microtus mogollonensis; dotted circles in the United States [north of approximately $30^{\circ}$ latitude]). Models are based on modern climate conditions. 
A

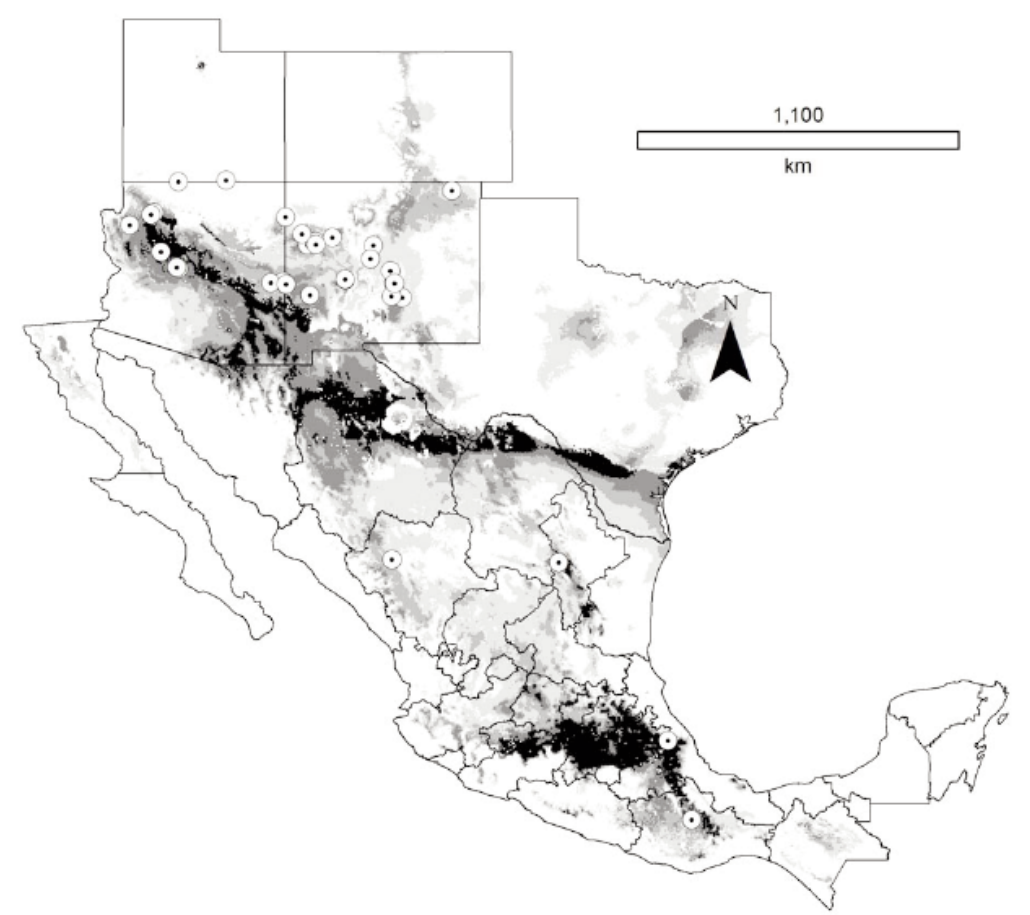

B

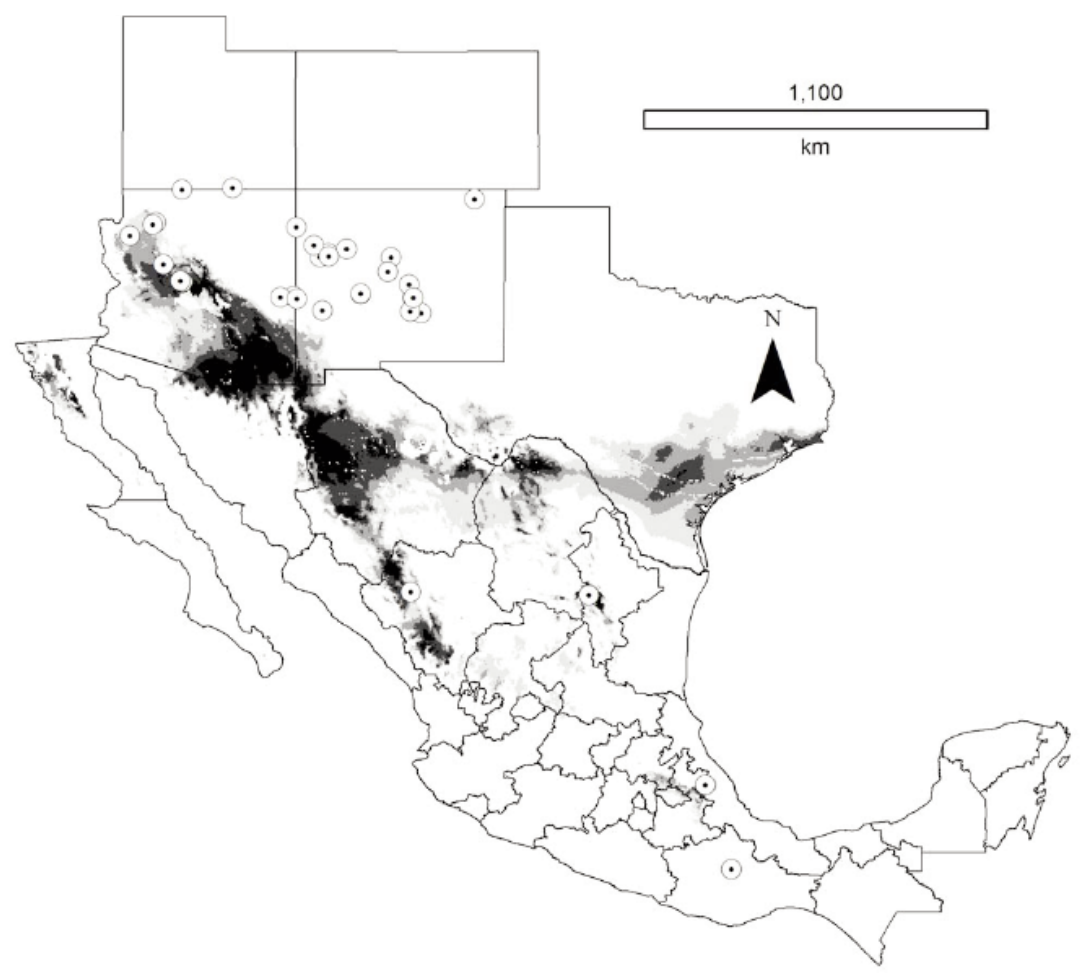

Fig. 3. Ecological niche models based on climate conditions from the Last Glacial Maximum (LGM): A, Mexican vole (Microtus mexicanus; dotted circles in Mexico [south of approximately $30^{\circ}$ latitude]); B, presumptive Mogollon vole (Microtus mogollonensis; dotted circles in the United States [north of approximately $30^{\circ}$ latitude]). 

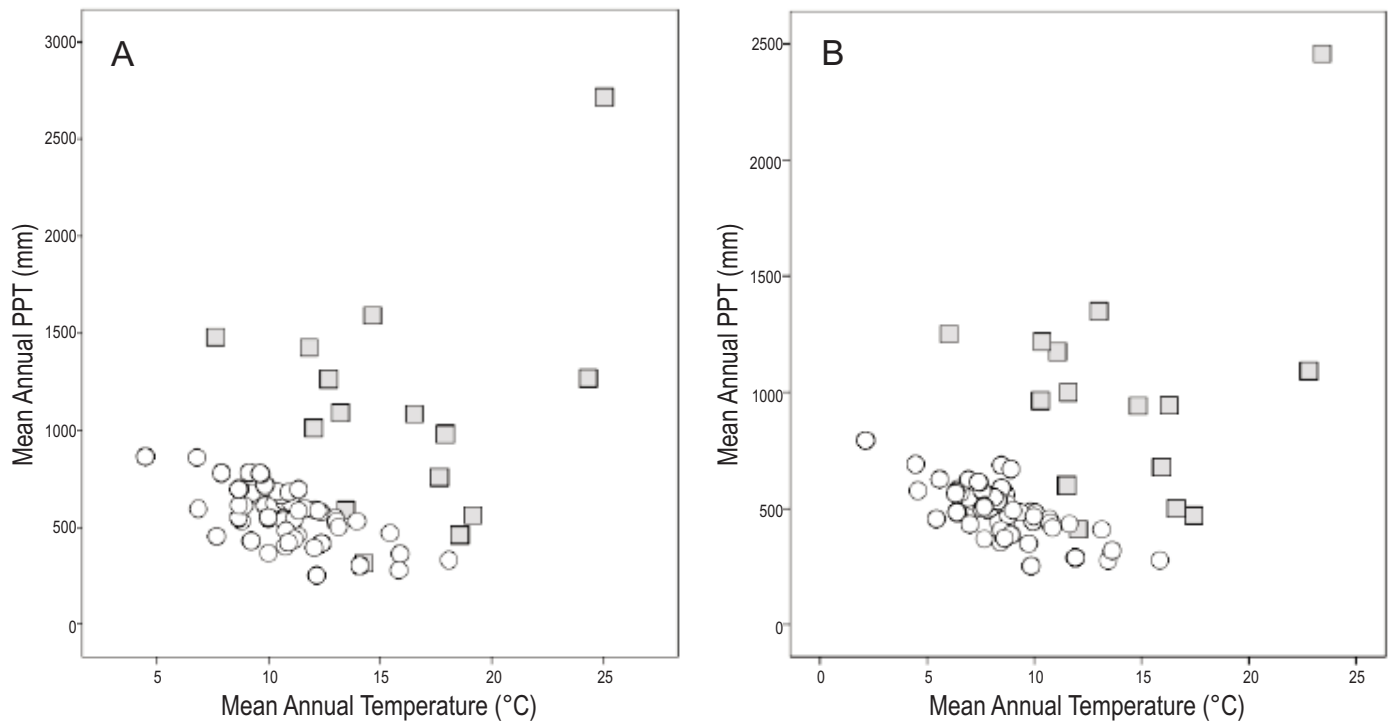

Fig. 4. The climate space occupied by the presumptive Mogollon vole (circles) and the Mexican vole (squares), as parameterized with modern (A) and LGM (B) climate conditions.

cytb gene from 62 samples of Microtus, including 44 samples of M. mexicanus (Appendix). Of the DNA segment analyzed, 221 sites were variable, and 134 sites were parsimonyinformative. Patterns of genetic variation conducted in MODELTEST v.3.7 (Posada and Crandall 1998) demonstrated a level of complexity best modeled by the HKY + I + G model of evolution with 6 free parameters; base frequencies were estimated as A, 30.3\%; C, $28.2 \%$; G, $13.4 \%$; and T, $28.1 \%$. The transition/transversion ratio was estimated at 2.63 , and values for the proportion of invariable sites (I) and the gamma shape parameter $(\mathrm{G})$ were estimated as 0.53 and 0.66 , respectively. Base frequencies observed in this study for cyt $b$ are similar to those reported in other studies of Microtus (Conroy and Cook 1999), and no significant deviations were found $\left(\chi^{2}=\right.$ $61.35, \mathrm{df}=180, P=1.00$ ).

Phylogeographic analyses of the $c y t b$ gene recovered the "Pennsylvanicus clade" (Conroy and Cook 2000b), the "Asian clade" (Conroy and Cook 2000b), and the "Mesoamerican endemic clade" (Conroy et al. 2001) identified in previous analyses. There is also additional topological support for Microtus californicus as sister to M. mexicanus (Conroy and Cook 2000b); thus, M. californicus was used as an outgroup for $M$. mexicanus in subsequent analyses.
Support for genetically distinct Mexican vole lineages in the southwestern United States and Mexico was examined through analyses of cyt $b$ variation. The Bayesian phylogram demonstrated a $100 \%$ posterior probability for a west-east split, with samples from the southwestern United States and northern Sierra Madre Occidental as 2 distinct subclades within the western clade, and the remaining samples from Mexico in the eastern clade. The topological positioning of the Sierra Madre Occidental samples with samples from the southwestern United States, which was congruent across all phylogenetic analyses, is a departure from the "north-south" (i.e., United StatesMexico) split suggested from previous analyses (e.g., Frey 2009). The phylogram also depicted moderate support for a subclade that consisted of samples from the White and Hualpai Mountains of east central and northwestern Arizona. All subclades sampled from Mexico demonstrated longer branch lengths indicative of genetic divergence (Fig. 6).

\section{Analysis of Molecular Variation}

The highest levels of cyt $b$ molecular diversity were indicated for Oaxaca $(\pi=0.028 \pm$ $0.012)$ and Durango $(0.043 \pm 0.007)$, Mexico (Table 1). Further analyses of molecular diversity of the west-east clade division indicated higher diversity for the eastern clade across 

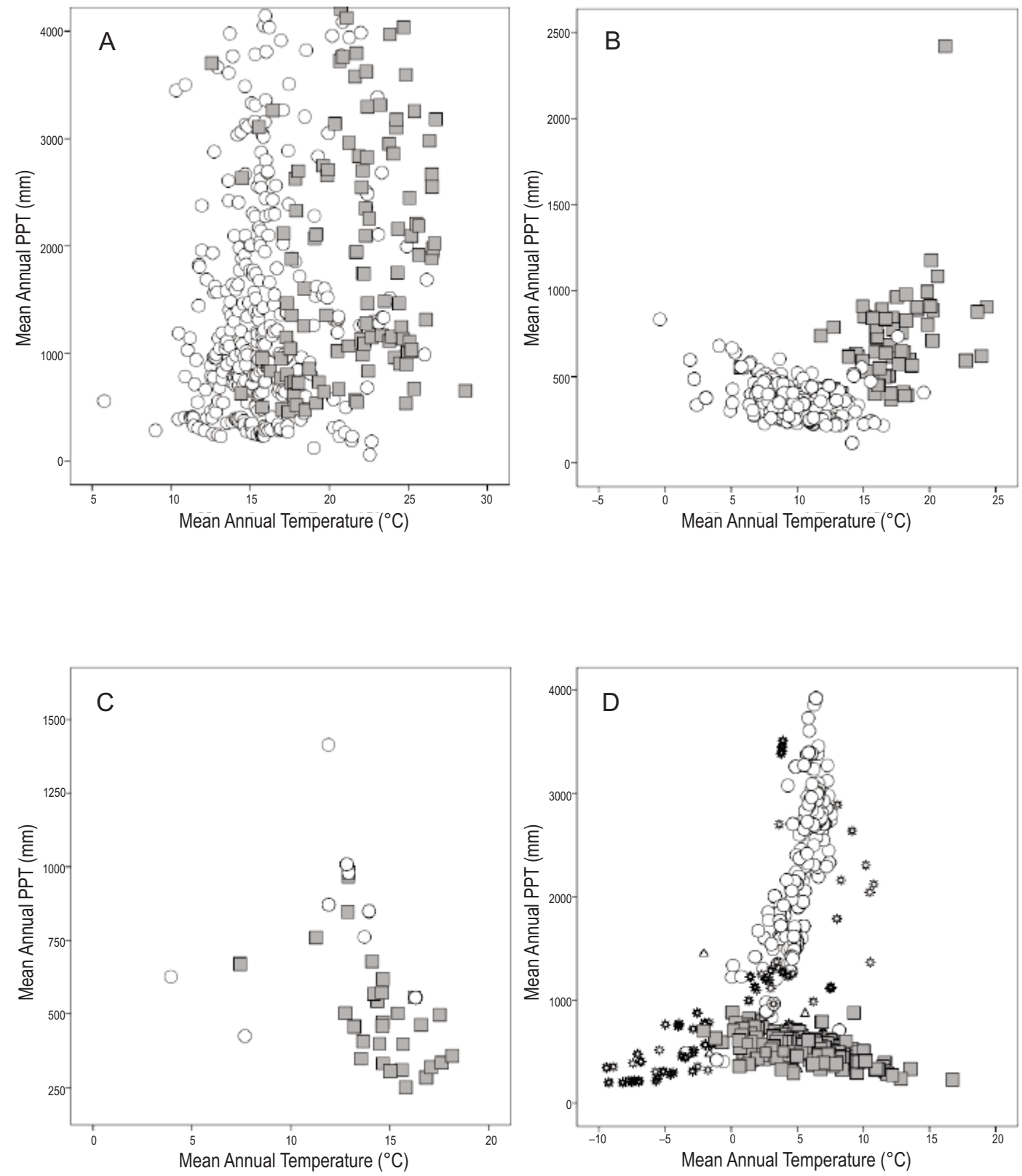

Fig. 5. Analyses demonstrated climatic separation between clades for codistributed taxa and Microtus congeners. Plots of mean annual precipitation to mean annual temperature for northern (circles) and southern (squares) clades: A, Sigmodon hispidus; B, Peromyscus truei, and C, Microtus californicus; D, also shown is separation between clades of Microtus longicaudus (Conroy and Cook 2000a) as southern Rockies clade (filled squares), northwest and island clades (circles), and central clade (asterisks).

most parameters $(\pi=0.031 \pm 0.005)$ compared to the western clade (Table $1, \pi=0.021 \pm$ $0.001)$. The average evolutionary divergence between Mexican vole lineages in the southwestern United States and Mexico estimated using the uncorrected p-distance averaged 8.23\% (range 6.18\%-10.3\%). Net divergence between western and eastern clades was 7.93\%, based on average divergence within each clade of $0.27 \pm 0.003$ and $0.33 \pm 0.004$, respectively. 


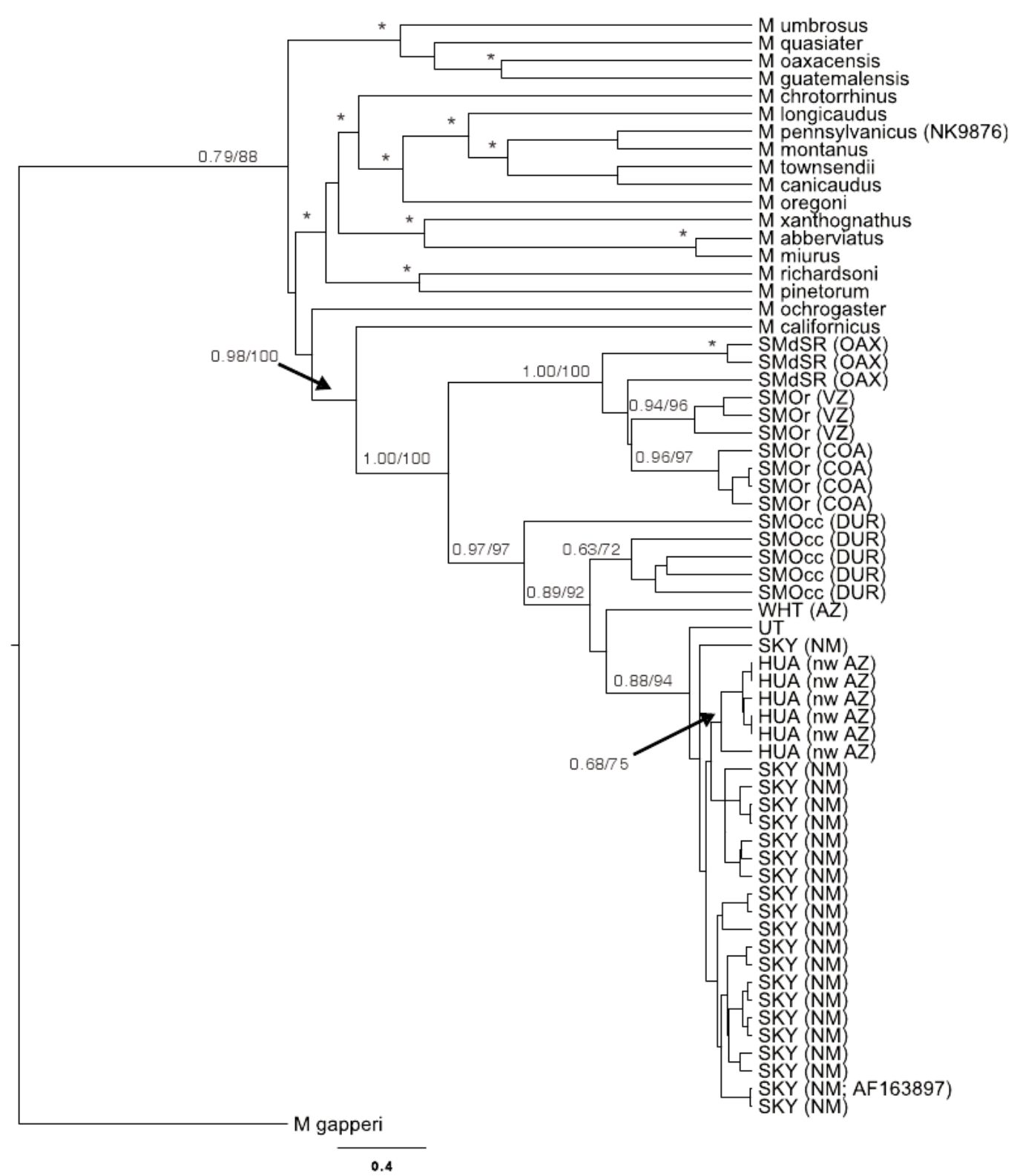

Fig. 6. A Bayesian phylogram derived from the cytochrome $b$ gene. The analysis consisted of 44 Microtus mexicanus samples. The tree was rooted with the outgroup Myodes gapperi, a sister taxon to Microtus (Conroy and Cook 2000b). Additional support for the topology is represented by 100 bootstrap replicates of a maximum likelihood topology. The model of evolution selected for the Bayesian and maximum likelihood analyses was the HKY + I + G with 6 free parameters. The eastern clade comprises samples from the Colorado Plateau (COP [AZ]), the mountains of New Mexico (SKY [NM]) and the northern Sierra Madre at Durango, Mexico (SMOcc [DUR]). The western clade comprises samples from the northern extent of the Sierra Madre Oriental at Coahuila (SMOr [COA]), its southern terminus at Veracruz (SMOr [VZ]), and the Sierra Madre del Sur in Oaxaca (SMdelSur [OAX]). Support for major nodes is indicated as a Bayesian posterior probability to the left of each slash, and bootstrap values to the right.

The average distance is less than the genetic divergence between $M$. mexicanus and its sister taxon, M. californicus (11.6\%), but it is greater than that between clades of $M$. californicus $(4.46 \%)$, for which separate species status was recommended (Conroy and Neuwald 2008). Our 
TABLE 1. Summary statistics for cytochrome $b$ clades of the Mexican vole. Parameters include the number of polymorphic sites $(S)$, nucleotide diversity $(\pi)$, theta $(\Theta)$, and the number of unique haplotypes $(h)$. Population abbreviations include the following: Colorado Plateau (COP), composed of Microtus mexicanus hualpaiensis (HUA) and M. m. mogollonensis (WHT), eastern New Mexico (M. m. mogollonensis [SKY(NM)], western New Mexico (M. m. guadalupensis [SKY(NM)], Utah (M. m. navajo [UT]), Sierra Madre Occidental in Durango, Mexico (M. m. madrensis [SMOcc, DUR]), Sierra Madre Oriental in Coahuila, Mexico (M. m. subsimus [SMOr, COA]), Sierra Madre Oriental in Veracruz, Mexico (M. $m$. mexicanus [SMOr, VZ]), and Sierra Madre del Sur in Oaxaca, Mexico (M. m. fulviventer [SMdelSur, OAX]). Sample sizes (N) are also provided.

\begin{tabular}{llrrrrr}
\hline Clade & Population & $N$ & $S$ & $\pi$ & $\Theta$ & $h$ \\
\hline WEST & COP (HUA+WHT) & 7 & 44 & $0.024 \pm 0.013$ & 0.0030 & 5 \\
& SKY+UT & 22 & 1 & $0.003 \pm 0.002$ & 0.003 & 1 \\
& SMOcc (DUR) & 5 & 32 & $0.042 \pm 0.007$ & 0.045 & 5 \\
Overall & & 34 & 1 & $0.021 \pm 0.001$ & 0.022 & 2 \\
EAST & SMOr (COA) & 4 & 9 & $0.005 \pm 0.002$ & 0.007 & 3 \\
& SMOr (VZ) & 3 & 2 & $0.009 \pm 0.004$ & 0.009 & 2 \\
Overall & SMdelSur (OAX) & 3 & 14 & $0.025 \pm 0.008$ & 0.025 & 3 \\
\hline
\end{tabular}

analyses demonstrate similar genetic distances for sister taxa, such as M. miurus-M. abbreviatus $(1.4 \%)$ and $M$. longicaudus $-M$. oregoni $(13.0 \%)$ as reported in other studies (Conroy and Neuwald 2008). Therefore, the net divergence observed between clades of the Mexican vole approach the level of divergence reported for other Microtus species. The average genetic distance between samples from Durango and the southwestern United States $(5.4 \%)$ was less than the genetic distance between Durango samples and the remaining populations in Mexico (8.8\%). The average genetic distance between Mexican vole clades and M. californicus was slightly greater for the western clade $(0.12)$ than the eastern clade (0.11). Genetic divergence between the western and eastern clades of the Mexican vole estimated using the Kimura 2-parameter distance was somewhat higher (average 9.1\% \pm 0.004 , range $7.0 \%-11.6 \%$ ), and the western clade demonstrated greater genetic distance to the sister taxon M. californicus (range $12.3 \%-15.0 \%$ ) compared to the eastern clade (range $10.6 \%-14.2 \%$ ).

Vole clades in Mexico demonstrated greater genetic diversity compared to those in the southwestern United States. The highest levels of cyt $b$ molecular diversity were indicated for Veracruz $(\pi=0.034 \pm 0.001)$ and Durango $(0.049 \pm 0.029)$, Mexico (Table 1). Demographic expansion was supported for samples from New Mexico $(r=0.26, F s=-1.69, P=0.000)$ and the Sierra Madre Oriental at Coahuila, Mexico $(r=0.22, F s=-2.18, P=0.020)$, although the latter result is tentative due to a small sample size.

\section{Clade Divergence Estimation}

We rejected the assumption of rate homogeneity among all branches and estimated clade divergence under a relaxed molecular clock assumption. Divergence models that used only fossil calibration priors performed significantly worse compared to models that incorporated both fossil and molecular calibration priors. When only the fossil priors were used (3.5 Ma for Myodes-Microtus and $0.5 \mathrm{Ma}$ for the divergence of Microtus in North America), ESS values were low $(<20)$ and yielded a relatively poor marginal likelihood $(-\ln L=8896.82)$. When a molecular estimate was used in place of the $0.5 \mathrm{Ma}$ divergence of Microtus radiation in North America, significant improvement was noted in the marginal likelihood $(-\operatorname{lnL}=8757.08)$ and ESS (Table 2). The large improvement in the marginal likelihood between the models (Model A, Model B, see Table 2) indicates that Model $\mathrm{B}$, which incorporated both fossil and molecular calibration priors, did a better job of explaining the observed data (Drummond and Rambaut 2007). The vole populations of southern Mexico at Oaxaca, Mexico, within the Sierra Madre del Sur demonstrated the earliest divergence from the middle Pleistocene (ca. 1.01 Ma, range 0.80-1.3), followed by the population in the Sierra Madre Occidental at Durango, Mexico (ca. 0.91 Ma, range 0.53-1.23). Northern vole populations in the United States demonstrated the most recent divergence, during the late Pleistocene to early Holocene (ca. $0.18 \mathrm{Ma}$, range 0.04-0.35). In general, these estimates are earlier than the $0.38-0.16 \mathrm{Ma}$ 
TABLE 2. Estimates of divergence for 6 clades of the Mexican vole. Divergence was estimated using a lognormal uncorrelated molecular clock and 10,000,000 iterations for 2 models. The first model (A) included priors derived from fossil data, $3.5 \pm 0.5$ Ma divergence as an external calibration point for the split between Myodes and Microtus (Chaline and Graf 1988), and a $0.5 \pm 0.2$ Ma divergence for Microtus in North America (Hoffmann and Koeppl 1985). The second model (B) incorporated the 3.5 Ma \pm 0.5 Myodes-Microtus divergence and a prior of $1.3 \pm 0.5 \mathrm{Ma}$ for radiation of Microtus in North America based on molecular estimates (Conroy and Cook 2000b). The mean divergence ( $\left.\mathrm{T}_{\mathrm{MRCA}}\right)$, effective sample size (ESS), and range of divergence estimate (Range) are reported. Clade abbreviations are as in Table 1.

\begin{tabular}{|c|c|c|c|c|}
\hline Clade & Method & $\mathrm{T}_{\mathrm{MRCA}}(\mathrm{Ma})$ & ESS & Range (Ma) \\
\hline \multirow[t]{2}{*}{$\mathrm{COP}(\mathrm{HUA}+\mathrm{WHT})$} & A & 0.01 & 6.89 & $0.003-0.05$ \\
\hline & $\mathrm{B}$ & 0.11 & 2495.18 & $0.04-0.18$ \\
\hline \multirow[t]{2}{*}{$\mathrm{SKY}(\mathrm{NM})$} & A & 0.03 & 5.83 & $0.002-0.10$ \\
\hline & $\mathrm{B}$ & 0.25 & 709.05 & $0.15-0.35$ \\
\hline \multirow[t]{2}{*}{ SMOcc (DUR) } & A & 0.17 & 5.865 & $0.01-0.55$ \\
\hline & $\mathrm{B}$ & 0.91 & 360.64 & $0.53-1.23$ \\
\hline \multirow[t]{2}{*}{ SMOr (COA) } & A & 0.02 & 6.79 & $0.007-0.07$ \\
\hline & $\mathrm{B}$ & 0.17 & 2910.78 & $0.07-0.28$ \\
\hline \multirow[t]{2}{*}{ SMOr (VZ) } & A & 0.05 & 6.521 & $0.002-0.18$ \\
\hline & B & 0.41 & 1436.09 & $0.18-0.68$ \\
\hline \multirow[t]{2}{*}{ SMdSR (OAX) } & A & 0.12 & 6.02 & $0.006-0.38$ \\
\hline & $\mathrm{B}$ & 1.02 & 1093.42 & $0.80-1.31$ \\
\hline
\end{tabular}

divergence of populations in Mexico suggested from morphological work (Frey 1989) but fit within the time frame of diversification suggested for closely related Microtus, such as M. longicaudus (0.92; Conroy and Cook 2000a) or Mesoamerican Microtus (middle Pleistocene; Conroy et al. 2001).

\section{DISCUSSION}

Our analyses of molecular variation indicate that M. mexicanus is comprised of a western and an eastern clade that demonstrate levels of genetic divergence within the range of other Microtus species. The average divergence between the 2 highly supported clades recovered in this study is $8.23 \%$ uncorrected p, similar to recognized species of Microtus such as M. arvalis-M. rossiaemeridionalis $(6.5 \%$, Conroy and Cook 2000b ), M. middendorffi-M. arvalis $(9.1 \%$, Conroy and Cook 2000b) or M. miurus-M. abbreviatus (1.5\%, Conroy and Cook 2000b; 0.54\%, Conroy and Neuwald 2008). Additionally, the average divergence between clades of the Mexican vole is greater than that reported for the northern and southern clades of the California vole (4.46\% uncorrected $\mathrm{p})$, for which separate species designation was recommended (Conroy and Neuwald 2008). Interestingly, the genetic distance between the subclades of the western clade (5.4\% uncorrected p) also approached or exceeded distances between recognized or proposed Microtus species. This result suggests that the current taxonomy of the Mexican vole, even with the inclusion of M. mogollonensis, may underrepresent the actual number of Microtus species in Mexico. Additional molecular work, particularly in the nuclear genome, is needed to help clarify these issues and provide additional insights into the colonization and diversification dynamics of this species group.

Our genetic results add additional support for the recognition of the Mogollon vole, $M$. mogollonensis, which has been the subject of some debate (Fitzgerald et al. 1994, Musser and Carleton 2005). Taxonomic revision has been recommended from studies of morphological, karyotypical, and molecular evidence (Lee and Endler 1977, Judd 1980, Wilhelm 1982, Modi 1987, Frey and LaRue 1993, Frey 2009). The topology uncovered in this study is a departure from previous studies that have suggested a "north-south" division within the Mexican vole, with populations in the United States being a species distinct from populations in Mexico. In part, the north-south dichotomy was based on differences in the diploid chromosome number, morphology, and allozyme variation between the 2 regions (Modi 1987, Frey 1989, 2009).

Patterns of genetic variation within the Mexican vole, and the extensive spatial scale over which these variations are distributed, strongly implicate the role of climate. Climatic fluctuations during the Pleistocene may have influenced the patterns of gene flow by altering the connectivity of suitable habitat. The topology of the western clade is instructive. The genetic similarity between the Durango and the southwestern United States subclades 
indicates historical gene flow along the Sierra Madre Occidental. Dispersal of individuals between the 2 regions was likely possible through pinyon-juniper woodlands that covered the Chihuahuan and Sonoran deserts into the middle Pleistocene (Metcalfe 2006). At the same time, the longer branch lengths, higher diversity and earlier divergence of the Durango subclade (Fig. 6; Tables 1,2) suggest a cessation of gene flow with populations to the north during the middle Pleistocene. Despite the existence of pine-oak forests at lower elevations (Morafka 1977, Toledo 1982, van Devender 1987, Castoe et al. 2007), areas of suitable vole habitat may have been increasingly fragmented beginning in the middle to late Pleistocene. The niche models seem to indicate that only a slim southern (i.e., Mexico) extension of suitable habitat is predicted for the presumptive M. mogollonensis in the model parameterized with modern climate conditions (Fig. 2b). Patterns of genetic variation in the eastern clade appear to suggest the same southto-north fragmentation of vole habitat, with the more southern populations characterized by higher diversity, longer branch lengths, and earlier divergence (Fig. 6; Tables 1, 2). Vole populations sampled from Mexico were generally older than populations from the United States. Despite the topological position of Durango as a subclade to the samples from the southwestern United States, all vole populations sampled from Mexico demonstrated longer branch lengths and higher molecular diversity compared to populations in the United States (Fig. 6, Table 1). Assuming large size and isolation, the number of intrapopulation mutations may be a function of the time elapsed since lineages diverged: older populations should harbor greater molecular diversity (Hoffman and Blouin 2004). A multimodal haplotype distribution, indicative of long-term diversification in situ, also characterized most subclades in Mexico. The relaxed molecular lock dating method placed the earliest divergence for the subclades at Durango and Oaxaca, which also exhibited the highest number of polymorphic sites (Tables 1,2). An older origin for populations in Mexico has also been suggested by studies of morphology and chromosomal variation (Judd 1980, Wilhelm 1982, Frey 1989).

Analyses of climate parameters demonstrated additional support for the role of Pleistocene climate variability on diversification.
The ecological niche model parameterized with modern climate conditions predicted a distinct climate space for M. mexicanus and the presumptive M. mogollonensis (Fig. 2a, 2b). The Last Glacial Maximum model (LGM) indicated a lack of suitable habitat in the southwestern United States for the presumptive Mogollon vole (Fig. 3b). This would appear to indicate that colonization into the Southwest occurred following the LGM. This result is congruent with molecular analyses, which demonstrated shallow branch lengths, reduced molecular diversity, and demographic expansion in the southwestern subclade (Fig. 6, Table 1). Comparison of the niche models for $M$. mexicanus demonstrates a significant reduction in the distribution of suitable habitat for modern compared to LGM (Fig. 2a, 3a), which suggested isolation of vole populations. Generally, this was also suggested by the molecular analyses, which depict longer branch lengths, demographic stasis, and earlier divergence for subclades of the Mexican vole (Fig. 6; Tables $1,2)$. Statistical analyses of climate parameters also demonstrated significantly different climatic spaces between the clades (Figs. 4a, 4b). In concert with differences in the climate space occupied by each lineage, isolated vole populations may have been subjected to differential selection pressures that acted, along with differences in metrics such as population size, to exacerbate genetic differentiation.

It is worth noting that other studies of codistributed rodent taxa demonstrate topological and climatic separation similar to $M$. mexicanus (Janecek 1990, Peppers and Bradley 2000, Edwards and Bradley 2002). In a study of allozyme variation in Sigmodon hispidus (Janecek 1990), the author suggested that the northern and southern clades represent separate species. Similar recommendations were made from a study of S. hispidus, in which the population in northern Mexico, including a sample from Durango, was sister to a subclade from the United States, distinguished by relatively high genetic distances (11.44\%-11.86\%, Peppers and Bradley 2000). The genetic distances between Peromyscus truei (southern Mexico) and P. gratus (southwestern United States) were sufficient for species recognition $(10.63 \%$, Durish et al. 2004). Similarly, a phylogeographic study of Neotoma mexicana demonstrated a subclade from Durango as sister to a subclade from the 
southwestern United States separated by moderate genetic distances (about 4.0\%, TamuraNei model). On the basis of genetic distances between the northern and southern clades in Mexico (8.82\%-10.8\%), the authors recommended a separate specific designation for lineages in northern and southern Mexico (Edwards and Bradley 2002).

Our analyses of climatic variation for codistributed taxa and Microtus congeners also mirrored the climatic separation between clades for the Mexican vole. Statistical analyses of taxa that occupy a similar distribution to the Mexican vole (hispid cotton rat, Mexican woodrat, and the piñon mouse) depicted significant climatic separation between clades (Fig. 5). This was also true for the California vole ( $M$. californicus). In the latter case, significant climatic separation between a northern and southern clade was demonstrated previously, which, together with genetic distances, led the authors to recommend specific designation for each clade (Conroy and Neuwald 2008).

The similarities between these analyses seem to suggest a predictable relationship between climatic separation and species status, but this was not always the case. For example, significant climatic separation was demonstrated between clades of the long-tailed vole, although no taxonomic revisions are recommended (Conroy and Cook 2000a). This study revealed a deep climate separation between the southern Rockies and the northwest/island clades, and further phylogenetic study may support the climate results. Likewise, the genetic distance between southwestern United States and northern Mexico clades of the Mexican woodrat $(4.0 \%)$ was not sufficient to revise species status, although our analyses demonstrated significant climatic separation (data not shown). This result insinuates the contribution of other factors-such as the time since lineage divergence, genetic drift, and population size-on genetic diversity. While differences in climate alone are not likely to foster speciation, this study and the results of similar studies (Graham et al. 2004) suggest that the degree of clade separation along climatic axes may be an indirect proxy for incipient speciation. The role of climate variation on diversification is suspected when allopatric sister lineages reliably and consistently segregate along climate axes (Graham et al. 2004, Barnosky 2005), and this appeared to be the case here.
This study of the Mexican vole provides additional insight into the origins of biodiversity in the mountains of the southwestern United States and Mexico. While previous studies have provided important evidence for diversification within the Mexican vole (Frey 1989, 2009), this study represents a departure in 2 ways. First, this study analyzed a larger dataset from a wider geographical range of the species, which allowed for a more complete analysis of molecular variation. The ecological analyses highlighted the disparate climatic niches occupied by western and eastern vole lineages and suggested the role of climate variability in the diversification of the species. In the light of potential threats from humanmediated habitat and climate change, research that explores a mechanistic explanation for the origin and maintenance of the region's biodiversity is of fundamental and timely importance. A cadre of abiotic influences is proposed to explain the region's biodiversity, such as habitat heterogeneity, elevation and Pleistocene refugia (Fa and Morales 1993). While a few intriguing studies of rodent taxa suggest the action of vicariant processes to diversity in the region (Lamb et al. 1997, Sullivan et al. 2000), a surprising paucity of studies have examined taxa distributed across the spatial extent of the domain. These analyses, which link climate variability beginning in the middle Pleistocene to the phylogeographic structure in M. mexicanus, suggested a plausible scenario for the disjunct distribution of the species. This approach could easily be applied to studies of codistributed taxa such as Peromyscus melanotis, P. maniculatus, and Liomys irroratus (Dowler and Genoways 1978, AlvarezCastenada 2005, Dragoo et al. 2006) to add additional support for the influence of climateinduced vicariance in this exceptional region.

\section{ACKNOWLEDGMENTS}

A preliminary study of this species was assisted by the very capable Andrea N. Chavez while she was an undergraduate at the University of New Mexico. We extend sincere thanks to Dr. Joseph A. Cook and Cheryl Parmenter from the University of New Mexico's Museum of Southwestern Biology and to Dr. Barbara Lundrigan and Laura Abraczinskas from the Michigan State University Museum, who facilitated the loan of vole tissues used 
in the study. The manuscript was greatly improved by input from Dr. Robert P. Guralnick (University of Colorado), who assisted with modeling. The research was supported by grants to DLC from the American Society of Mammalogists (Grant-In-Aid 2005) and a Theodore Roosevelt Fund award from the American Museum of Natural History (2005).

\section{Literature Cited}

Alvarez-Castenada, T. 2005. Peromyscus melanotis. Mammalian Species 764:1-4.

Armstrong, D.M. 1972. Distribution of mammals in Colorado. University of Kansas Museum of Natural History Monograph 3:1-415.

Avise, J.C., AND D. WALKER. 1998. Pleistocene phylogeographic effects on avian populations and the speciation process. Proceedings of the Royal Society of London 265:457-463.

Barnosky, A.D. 2005. Effects of Quaternary climatic change on speciation in mammals. Journal of Mammalian Evolution 12:247-264.

Bromberg, C.H., P. Cash, C.J. Curtis, L. Goebel III, L. Irwin, J. Singer, D. VAN HoEwYK, AND J. WinKeLPLEK. 1995. Sequencher. Gene Codes Corporation, Ann Arbor, MI.

Cameron, G.N., and S.R. Spencer. 1981. Sigmodon hispidus. Mammalian Species 158:1-9.

Castoe, T.A., C.L. Spencer, and C.L. Parkinson. 2007. Phylogeographic structure and historical demography of the western diamondback rattlesnake (Crotalus atrox): a perspective on North American desert biogeography. Molecular Phylogenetics and Evolution 42:193-212.

Catzeflis, F.M., F.H. Sheldon, J.E. Ahlquist, and C.G. SIBLEY. 1987. DNA-DNA hybridization evidence of the rapid rate of muroid rodent evolution. Molecular Biology and Evolution 4:242-253.

Ceballos, G., and G. Oliva. 2006. Diversidad y conservacion de los mamiferos de Mexico. Pages 21-49 in G. Ceballos and G. Oliva, editors, Mamiferos Silvestres De Mexico. Fondo De Cultura Economica USA.

Chaline, J., And J.D. Graf. 1988. Phylogeny of the Arvicolidae (Rodentia): biochemical and paleontological evidence. Journal of Mammalogy 69:22-33.

Collins W.D., P.J. Rasch, B.A. Boville, J.J. Hack, J.R. McCaA, D.L. Williamson, J.T. Kiehl, B. Briegleb, C. BITZ, S.J. Lin, ET AL. 2004. Description of the NCAR Community Atmosphere Model (CAM3). Technical Report NAR/TN-464+STR, National Center for Atmospheric Research, Boulder, CO. 226 pp.

Conroy, C.J., AND J.A. CoOK. 1999. MtDNA evidence for repeated pulses of speciation within arvicoline and murid rodents. Journal of Mammalian Evolution 6:221-245.

2000a. Phylogeography of a post-glacial colonizer: Microtus longicaudus (Muridae: Rodentia). Molecular Ecology 9:165-175.

2000b. Molecular systematics of a Holarctic rodent (Microtus: Muridae). Journal of Mammalogy 81:344-359.

Conroy, C.J., Y. Hortelano, F. Cervantes, and J.A. CoOK. 2001. The phylogenetic position of southern relictual species of Microtus. Mammalian Biology 66:332-344

Conroy, C.J., AND J.L. Neuwald. 2008. Phylogeographic study of the California vole, Microtus californicus. Journal of Mammalogy 89:755-767.

Crawford, M.H. 2007. Anthropological genetics: theory, methods and applications. Cambridge University Press, Cambridge, United Kingdom. 476 pp.

Dowler, R.C., AND H.H. Genoways. 1978. Liomys irroratus. Mammalian Species 82:1-6.

Dragoo, J.W., A. Lackey, K.E. Moore, E.P. Lessa, J.A. CoOK, And T.L. Yates. 2006. Phylogeography of the deer mouse (Peromyscus maniculatus) provides a predictive framework for research on hantaviruses. Journal of General Virology 87:1997-2003.

Drummond, A.J., S.Y.W. Ho, M.J. Phillips, and A. RamBAUT. 2006. Relaxed phylogenetics and dating with confidence. PLOS Biology 4:699-710.

Drummond, A.J., And A. Rambaut. 2007. BEAST: Bayesian evolutionary analysis by sampling trees. BMC Evolutionary Biology 7:214. doi:10.1186/1471-2148-7214

Durish, N.D., K.E. Halcomb, C.W. Kilpatrick, and R.D. BRADLEy. 2004. Molecular systematics of the Peromyscus truei species group. Journal of Mammalogy 85:1160-1169.

EdwaRds, C.W., AND R.D. BRADLEy. 2002. Molecular systematics and historical phylobiogeography of the Neotoma mexicana species group. Journal of Mammalogy 83:20-30.

EIsenberG, J.F. 1981. The mammalian radiation: an analysis of trends in evolution, adaptation, and behavior. University of Chicago Press, Chicago, IL. 630 pp.

ELITH, J. 2002. Quantitative methods for modeling species habitat: comparative performance and an application to Australian plants. Pages 39-58 in S. Ferson and M. Burgman, editors, Quantitative methods for conservation biology. Springer-Verlag, New York, NY. $325 \mathrm{pp}$.

FA, J.E., AND L.M. Morales. 1993. Patrones de diversidad e mamíferos de México. Pages 315-354 in T.P. Ramamoorthy, R. Bye, A. Lot, and J. Fa, editors, Diversidad Biológica de México. Orígenes y Distribución. Instituto de Biología, Universidad Nacional Autónoma de México, Mexico City, Mexico. 792 pp.

Felsenstein, J. 1981. Evolutionary trees from DNA sequences: a maximum likelihood approach. Journal of Molecular Evolution 17:368-376.

FINDLEY, J.S., AND C. JoNES. 1962. Distribution and variation of the voles of the genus Microtus in New Mexico and adjacent areas. Journal of Mammalogy 43: 154-166.

Fitzgerald, J.P., C.A. Meaney, and D.M. Armstrong. 1994. Mammals of Colorado. Denver Museum of Natural History and University Press of Colorado, Boulder, CO. 467 pp.

FrEY, J.K. 1989. Morphologic variation in the Mexican vole (Microtus mexicanus). Master's thesis, Emporia State University, Emporia, KS.

2009. Genetics of allopatric populations of the montane vole (Microtus montanus) and Mogollon vole (Microtus mogollensis) in the American Southwest. Western North American Naturalist 69:215-222.

FreY, J.K., AND C.T. LARUE. 1993. Notes on the distribution of the Mogollon vole (Microtus mogollonensis) in Arizona and New Mexico. Southwestern Naturalist 38:176-178. 
Frey, J.K., J.J. Root, C.A. Jones, C.H. Calisher, and B.J. BEATTY. 2002. New records of the Mogollon vole, Microtus mogollensis (Mearns, 1890), in southwestern Colorado. Western North American Naturalist 62:120-123.

FU, Y.X. 1997. Statistical tests of neutrality of mutations against population growth, hitchhiking and background selection. Genetics 147:915-925.

Galewski, T., M. Tilak, S. Sanchez, P. Chevret, E. ParADIS, AND E.J.P. DOUZERY. 2006. The evolutionary radiation of Arvicolinae rodents (voles and lemmings): relative contribution of nuclear and mitochondrial DNA phylogenies. BMC Evolutionary Biology 6:80.

Graham, C.H., S.R. Ron, J.C. Santos, C.J. Schneider, AND C. MORITZ. 2004. Integrating phylogenetics and environmental niche models to explore speciation mechanisms in Dendrobatid frogs. Evolution 58 1781-1793.

Guralnick, R.P., J. Wieczorek, R. Beaman, and R.J. Hijimans. 2006. BioGeomancer: automated georeferencing to map the world's biodiversity data. PLoS Biology 4:e381. doi:10.1371/journal.pbio.0040381

Hall, E.R. 1981. Mammals of North America. 2nd edition. John Wiley \& Sons, New York, NY. 1181 pp.

Harpending, H.C. 1994. Signature of ancient population growth in a low-resolution mitochondrial DNA mismatch distribution. Human Biology 66:591-600.

Hedges, S.B., and S. Kumar. 2004. Precision of molecular time estimates. Trends in Genetics 20:242-247.

Hijmans, R.J., S.E. Cameron, J.L. Parra, P.G. Jones, and A. JARVIS. 2005. Very high resolution interpolated climate surfaces for global land areas. International Journal of Climatology 25:1965-1978.

Ho, S.Y.W. 2007. Calibrating molecular estimates of substitution rates and divergence times in birds. Journal of Avian Biology 38:409-414.

Ho, S.Y.W., U. SAarma, R. Barnett, J. HaIle, and B. SHAPIRO. 2007. The effect of inappropriate calibration: three case studies in molecular ecology. PLoS One 3:e1615. doi:10.1371/journal.pone.0001615.

Hoffman, E.A., AND M.S. Blouin. 2004. Historical data refute recent range contraction as cause of low genetic diversity in isolated frog populations. Molecular Ecology 13:271-276.

Hoffmann, R.S., AND J.W. KoEprl. 1985. Zoogeography. Pages 84-115 in R.H. Tamarin, editor, Biology of New World Microtus. Special Publication, American Society of Mammalogists 8. 893 pp.

HoFFMEISTER, D.F. 1951. A taxonomic and evolutionary study of the piñon mouse, Peromyscus truei. Biological Monographs 21:1-104

Huelsenbeck, J.P., AND F. RonQuist. 2001. MRBAYES Bayesian inference of phylogeny. Bioinformatics 17 $754-755$.

Hugall, A, C. Moritz, A. Moussalli, and I. Stanisic. 2002. Reconciling paleodistribution models and comparative phylogeography in the Wet Tropics rainforest land snail Gnarosophia bellendenkerensis (Brazier 1875). Proceedings of the National Academy of Sciences 99:6112-6117.

Irwin, D.M., T.D. Kocher, AND A.C. WILson. 1991. Evolution of the cytochrome $b$ gene of mammals. Journal of Molecular Evolution 32:128-144.

Jaarola, M., N. Martinkova, I. Gunduz, C. BrunhofF, J. Zima, A. Nadachowski, G. Amori, N.S. Bulatova, B. Chondropoulos, S. Fraguedakis-Tsolis, et AL. 2004 Molecular phylogeny of the speciose vole genus
Microtus (Arvicolinae, Rodentia) inferred from mitochondrial DNA sequences. Molecular Phylogenetics and Evolution 33:647-663.

JaneCEK, L.L. 1990. Genic variation in the Peromyscus truei group. Journal of Mammalogy 71:301-308.

JuDD, S.R. 1980. Observations of the chromosome variation in Microtus mexicanus (Rodentia: Microtinae). Mammalian Chromosome Newsletter 21:110-113.

Kiehl, J.T., and P.R. Gent. 2004. The Community Climate System Model, Version 2. Journal of Climate $17: 3666-3682$.

Kimura, M. 1980. A simple method for estimating evolutionary rates of base substitutions through comparative studies of nucleotide sequences. Journal of Molecular Evolution 16:111-120.

Knowles, L.L., B.C. Carstens, and M.L. Keat. 2007. Coupling genetic and ecological-niche models to examine how past population distributions contribute to divergence. Current Biology 17:940-946.

Lamb, T., T.R. Jones, and P.J. Wettstein. 1997. Evolutionary genetics and phylogeography of tassel-eared squirrels (Sciurus aberti). Journal of Mammalogy 78:117-133.

LEE, M.R., AND F.P.B. EndLER. 1977. Karyotypes of eight species of Mexican rodents (Muridae). Journal of Mammalogy 54:479-487.

Leon-Paniagua, L, A.G. Navarro-Siguenza, B.E. HerNANDEZ-Banos, And J.C. Morales. 2007. Diversification of the arboreal mice of the genus Habromys (Rodentia: Cricetidae: Neotominae) in the Mesoamerican highlands. Molecular Phylogenetics and Evolution 42:653-664.

McCormack, J.E., B.S. Bowen, and T.B. Smith. 2008. Integrating paleoecology and genetics of bird populations in two sky island archipelagos. BMC Biology $6: 23$

Medrano, J.F., E. Aasen, and L. Sharrow. 1990. DNA extraction from nucleated red blood cells. Biotechniques 8:43.

MetCalFe, S.E. 2006. Late Quaternary environments of the Northern Deserts and the Central Trans-Volcanic Belt of Mexico. Annals of the Missouri Botanical Gardens 98:258-273.

Mittermeier, R.A., G.P. Robles, and M. Hoffman. 2005. Hotspots revisited: earth's biologically richest and most endangered terrestrial ecoregions. Conservation International, Washington, DC. 392 pp.

ModI, W.S. 1987. Phylogenetic analyses of chromosomal banding patterns among the Nearctic Arvicolidae (Mammalia: Rodentia). Systematic Zoology 36:109-136.

Modi, W.S., AND M.R. LEE 1984. Systematic implications of chromosomal banding analyses of populations of Peromyscus truei (Rodentia: Muridae). Proceedings of the Biological Society of Washington 97: $716-723$.

MorAFKA, D.J. 1977. A biogeographic analysis of the Chihuanhuan Desert through its herptofauna. Dr. W. Junk, B.V.M. Publishers, The Hague, The Netherlands. $321 \mathrm{pp}$.

Musser, G.G., and D.M. Carleton. 2005. Superfamily Muroidea. Pages 894-1531 in D.E. Wilson and D.M. Reeder, editors, Mammal species of the world: a taxonomic and geographic reference. 3rd edition. Johns Hopkins University Press, Baltimore, MD. 2142 pp.

Peppers, L.L., AND R.D. BRadLey. 2000. Molecular systematics of the genus Sigmodon. Journal of Mammalogy 81:332-343. 
Peterson, A.T., M.A. Ortega-Huerta, J. Bartley, V. Sanchez-Cordero, J. Soberon, R.H. Buddemeier, AND D.R.B. STOCKWELL. 2002. Future projections for Mexican faunas under global climate change. Nature 416:626-628.

Peterson, A.T., J. Soberon, and V. Sanchez-Cordero. 1999. Conservatism of ecological niches in evolutionary time. Science 285:1265-1267.

Phillips, S.J., R.P. Anderson, and R.E. Schapire. 2006. Maximum entropy modeling of species geographic distributions. Ecological Modeling 190:231-259.

Phillips, S.J., AND M. DUdIK. 2008. Modeling of species distributions with Maxent: new extensions and comprehensive evaluation. Ecography 31:161-175.

Posada, D., and K.A. Crandall. 1998. MODELTEST: testing the model of DNA substitution. Bioinformatics 14:817-818.

Repenning, C.A. 1990. Of mice and ice in the Late Pliocene of North America. Arctic 43:314-323.

Rozas, J., J.C. Sanchez-DelBarrio, X. Messeguer, and R. RozAs. 2003. DnaSP: DNA polymorphisms analyses by the coalescent and other methods. Bioinformatics 19:2496-2497.

SмiтH, F.A. 1997. Neotoma cinerea. Mammalian Species 564:1-8.

Smith, M.F., AND J.L. PatTon. 1993. The diversification of South American rodents: evidence from the mitochondrial sequence data for the Akodontine tribe. Biological Journal of the Linnean Society 50:149-177.

Sullivan, J., E. Arellano, and D.S. Rogers. 2000. Comparative phylogeography of Mesoamerican highland rodents: concerted versus independent response to past climatic fluctuations. American Naturalist 155:755-768.

Swenson, N. 2008. The past and future influence of geographic information systems on hybrid zone, phylo- geographic and speciation research. Journal of Evolutionary Biology 21:421-434.

SwOFFORD, D.L. 2002. Paup*: phylogenetic analysis using parsimony (*and other methods). Version 4.0b10. Sinauer Associates, Inc., Sunderland, MA.

TAjIMA, F. 1989. Statistical method for testing the neutral mutation hypothesis by DNA polymorphism. Genetics 123:585-595.

Tamura, K., J. Dudley, M. Nei, and S. Kumar. 2007. MEGA4: molecular evolutionary genetics analysis (MEGA) software version 4.0. Molecular Biology and Evolution 24:1596-1599.

Toledo, V.M. 1982. Pleistocene changes of vegetation in tropical Mexico. Pages 93-111 in G.T. Prance, editor, Biological diversification in the tropics. Columbia University Press, New York, NY.

VAN DEvender, T.R. 1987. Holocene vegetation and climate in the Puerto Blanco Mountains, southwestern Arizona. Quaternary Research 27:51-72.

Wilhelm, D.E. 1982. Zoogeographic and evolutionary relationships of selected populations of Microtus mexicanus. Occasional Papers of the Museum of Texas Tech University 75:1-29.

Zakrzewski, R.J. 1985. The fossil record. Pages 1-51 in R.H. Tamarin, editor, Biology of New World Microtus. American Society of Mammalogists, Special Publication 8. 893 pp.

ZwICKL, D.J. 2006. Genetic algorithm approaches for the phylogenetic analysis of large biological sequence datasets under the maximum likelihood criterion. Doctoral dissertation, University of Texas, Austin, TX.

Received 4 June 2010 Accepted 6 January 2011

See Appendix on page 194. 
APPENDix. Museum catalog numbers and localities for 44 Microtus specimens from the Museum of Southwestern Biology (NK) and Michigan State University Museum (MSUM) used in the analysis of cytochrome $b$ gene sequence variation. A Myodes sequence and the sequences from 18 additional Microtus species from GenBank (AF numbers) were used to test the monophyly of Microtus mexicanus.

\section{Microtus mexicanus \\ MEXICO: CoAhuila: $10 \mathrm{mi}$. E San Antonio de las Ala-} zanas (NK9541, NK9542, NK9543, NK9544).

MEXICO: DURANGo: 18 mi. SSW Tepehuanes, pine-oak sacaton (MSUM10540, MSUM10542, MSUM10547, MSUM16367, MSUM16368).

MEXICO: OAXaca: $15.9 \mathrm{mi}$. N (by road) Guelato De Juarez (NK9688, NK9690, NK9695).

MEXICO: VeracruZ: 1.5 mi. S Altotonga (NK 9706 , NK9707, NK9708).

Microtus mogollonensis (presumptive)

USA: ArIzonA: Arizona: Apache Co.-(NK20108, originally identified as M. montanus). Yavapai Co.-Prescott National Forest, Bradshaw Mountains, Turkey Creek, (NK20053); Bradshaw Mountains, Godwin (NK20940, NK20941, NK29042); Santa Maria Mountains, Pine Creek (NK20929, NK20930).

USA: New Mexico: Bernalillo Co.-Residence of Bill Degenhardt, Juan Thomas (NK28499); 5 mi. S, 2 mi E of Cedro. Catron Co.-Apache Creek (NK133563, NK136225); Elk Mountains (NK29061, NK29062); Engineer Spring Canyon, $3 \mathrm{mi}$. W, $0.75 \mathrm{mi}$. N Luna (NK20464). Cibola Co.-Ojo Redondo Campground, Zuni Mountains (NK20002); 6 mi. N, 14 mi. E Grants (NK9182). Lincoln Co.-Jicarilla Mountains, $0.9 \mathrm{mi}$. SE Jicarilla (NK20767, NK20769); Sacramento Mountains, Eagle Creek, 1.5 mi. W Hwy. 95 (NK20716). McKinley Co.-Zuni Mountains, McGaffey Lake (NK20287, NK121579 [originally identified as M. montanus]). Socorro Co.-Magdalena Mountains, Meadow East W1 (NK19605); Magdalena Mountains, South Baldy Meadow (NK19643). Torrance Co.-1.7 mi. S, $4.6 \mathrm{mi}$. W Manzano, Red Canyon Campground (NK9292, NK9296). Union Co.-Sierra Grande, 3 mi. S, 3 mi. W Des Moines (NK9219, NK9222 [GenBank AF163897]); Valencia Co.—6.7 mi. S, 14 mi. W Grants, Agua Fria Creek (NK2703, NK8710).

USA: UTAH: San Juan Co.-Navajo Mountain (NK20983).

Microtus abbreviatus

USA: ALASKA: St. Matthew Island (AF163890).

Microtus californicus

USA: CALIFORNIA: Contra Costa Co.-no specific locality given (AF163891).

Microtus canicaudus

USA: Oregon: Benton Co. $-20 \mathrm{~km} \mathrm{~N}$ Corvallis (AF163892).
Microtus chrotorrhinus

USA: Minnesota: Cook Co.-no specific locality given (AF163893)

Microtus guatemalensis

MEXICO: Chiapas: Cerro Tzontehuitz, $13 \mathrm{~km}$ NE San Crisotbal de las Casas, Mpio. Chamala (AF410262).

Microtus longicaudus

USA: ALASKA: Yakutat, beach near Cannon Beach Picnic Area (AF119267).

Microtus miurus

USA: ALASKa: Chandalar Shelf, mile 239.4 Dalton Hwy. (AF163899).

Microtus montanus

USA: NEVADA: Lincoln Co.-Kirch Wildlife Management Area ("Kirch15"; D.L. Crawford unpublished data).

Microtus oaxacensis

MEXICO: OAXACA: $11 \mathrm{~km}$ SE La Esperanza, Mpio. Santiago Comaltepec (AF410260).

Microtus ochrogaster

USA: Montana: Carbon Co.-1 mi. S Silesia, $500 \mathrm{~m} \mathrm{~W}$ Clarks Fork, Yellowstone (AF163901).

Microtus oregoni

USA: Washington: Clallam Co.—9.2 mi. S, 0.7 mi. W Port Angeles, T29N, R6W, Sec 29 (AF163903).

Microtus pennsylvanicus

USA: New Mexico: Lincoln Co._-Gallinas Mountains (NK9876 [originally identified as M. mexicanus, identified from molar morphology and molecular data by D.L. Crawford])

Microtus pinetorum

USA: ArKansas: Pulaski Co.-no specific locality given (AF163904).

Microtus quasiater

MEXICO: VeracruZ: 5 km W Naolinco, Mpio. Naolino (AF410259).

Microtus richardsoni

USA: ORegon: Linn Co.-1.5 mi. N Big Lake, Hayrock Butte, T13S, R7E, Sec 35 (AF163905).

Microtus townsendii

USA: ORegon: Benton Co.-6.5 km SSE of Alsea, $6 \mathrm{~km}$ NNE of Prairie Mountain (AF163906).

Microtus umbrosus

MEXICO: OAXACA: Cerro Zempoaltepetl, $5 \mathrm{~km} \mathrm{~N} \mathrm{Sta.}$ Ma. Yacochi. Mpio. Tlahuitoltepec (AF410261).

Microtus xanthognathus

USA: ALASKa: Hughes Quad (AF163907).

Myodes gapperi

USA: ALASKA: Stikine River (GenBank AF272637). 